\title{
Effects of Prescribed Fire at Two Frequencies on N Mineralization and Nitrification at Two Spatial Scales in Mixed-Oak Forests
}

\author{
R.E.J. Boerner ${ }^{1}$ and J.A. Brinkman \\ Department of Evolution, Ecology, and Organismal Biology \\ Ohio State University \\ 318 West $12^{\text {th }}$ Avenue \\ Columbus, OH 43210 U.S.A.
}

\begin{abstract}
This study examined how fire frequency influences soil $\mathrm{C}$ and $\mathrm{N}$ dynamics in relation to spatial scale in two mixed-oak forest complexes in southern Ohio, U.S.A. We measured net $\mathrm{N}$ mineralization, net nitrification, total inorganic $\mathrm{N}$ (TIN) in the soil solution, and soil organic $C$ in plots of two sizes $\left(50 \mathrm{~m}^{2}\right.$ macroplots and $1 \mathrm{~m}^{2}$ microplots nested within the macroplots) in sites burned once (periodic fire treatment), in sites burned three times (annual fire treatment) and in unburned control sites. $\mathrm{N}$ mineralization rate increased with increasing fire frequency and net nitrification was greater in soils given annual fire sites than in soils given periodic fire or no fire (control); in contrast, neither TIN nor soil organic C content were affected significantly by fire. Geostatistical analysis designed to detect spatial autocorrelation (patch structure) at sizes of $0.2-0.8 \mathrm{~m}$ (microplots) and 1.0 - $7.8 \mathrm{~m}$ (macroplots) revealed significant patch structure in only approximately $1 / 3$ of the plots, and all of those had been recently burned. Comparison with studies done in these sites and others indicates that most spatial structure in soil properties occurs at ranges larger and smaller than those that could be resolved with this sampling design. Prior studies of the effects of fire on forests have suggested that fire enhances fine scale heterogeneity, though robust geostatistical analysis of patch structure has not often been part of such studies. The results presented here lend quantitative support that to the view that reintroduction of low intensity fire can restore native ecosystem spatial heterogeneity, and thereby help maintain overall plant species diversity and opportunities for the regeneration of diverse tree species.
\end{abstract}

keywords: fire frequency, oak forests, $N$ mineralization, geostatistics 


\section{INTRODUCTION}

Forests dominated by oak (Quercus spp.) once covered much of the United States east of the Mississippi River as far west as eastern Oklahoma and northeastern Texas. Prior to extensive alterations of this landscape by European-american settlers in the 19th century, these forests were subject to frequent, low intensity fires (Guyette and Cutter, 1991; Sutherland, 1997). These fires typically occurred during the dormant seasons (especially late autumn and early spring) and were caused by a combination of lightning and human activities.

During the early 20th century effective fire suppression became widespread, thus altering the fire regime. In addition, periodic cutting for fuel and wood products, clearing for agriculture, and more recently, chronic atmospheric $\mathrm{N}$ deposition have impacted these forests.

Efforts to restore mixed-oak forest ecosystems to conditions more similar to those that existed prior to widespread landscape alteration have been initiated over the last decade in a number of states. The goals of such projects include wildfire hazard reduction, facilitating regeneration and persistence of species which have come under threat as a result of fire suppression, countering the acidifying effects of atmospheric deposition rich in inorganic $\mathrm{N}$, improving watershed condition, and increasing sequestration of C. In particular, efforts involving the reintroduction of relatively frequent dormant season fires (using prescribed fire) have begun in Indiana, Missouri, and Ohio. This study chronicles one portion of the Ohio effort.

When prescribed burning is used for fuel and understory control in commercial conifer plantations, the plots to be burned are often modest in size and relatively homogeneous. Thus, results obtained from burning one part of a larger pine plantation can be extrapolated to estimate likely effects on larger areas by simple, linear scaling (e.g. Wells, 1971). In contrast, the forested landscapes in the American midlands which are the focus of large scale restoration efforts are often highly dissected, rugged, and heterogeneous in geomorphology, soils, and microclimate (e.g. Wolfe et al., 1949). In such sites, a specific understanding of the scaledependency of various ecological processes and properties is necessary before results from small study plots can be scaled-up to the landscape level.

Our earlier analyses of the effects of single and multiple prescribed burns in 3080 ha, watershed-scale treatment units in southern Ohio have demonstrated strong influences of landscape characteristics at scales from $10 \mathrm{~s}$ of $\mathrm{km}$ (inter site differences) to $100 \mathrm{~s}$ of $\mathrm{m}$ (aspect and elevation-related differences) in determining the effect of fire on forest floor fuel consumption, soil organic matter, and nutrient availability in the soils (Boerner et al., 2000b; Boerner and Brinkman, 2004b). We have also demonstrated significant spatial heterogeneity and patterning at scales of $20-200 \mathrm{~cm}$ in microbial biomass and activity in soils of unburned watersheds of this region (Morris and Boerner, 1999, Decker et al., 1999). As variations in soil physical and chemical properties at these scales have also been shown to strongly linked to diversity, species composition, and abundance of herbaceous understory plants and tree seedlings in this region (e.g. Crozier and Boerner, 1984; Hutchinson et al., 1999), spatial analysis offers an opportunity to link effects of fire on soil properties to changes in vegetation.

Despite a rapidly growing literature on spatial pattern analysis in forested ecosystems, we know of no data with which to determine if the effects of fire have significant spatial structure at intermediate ranges (i.e. those between $2 \mathrm{~m}$ and $100 \mathrm{~m}$ ), despite most routine sampling occurring at this scale. Within this context, the objective of this study was to determine 
how fire would affect soil organic $\mathrm{C}$ content, $\mathrm{N}$ mineralization, nitrification, and total inorganic $\mathrm{N}$ (TIN) in the soil solution at scales ranging from $10 \mathrm{~s}$ of $\mathrm{cm}$ to $\sim 10 \mathrm{~m}$, and whether single vs. multiple annual fires would differentially affect either the level or spatial dependency of these ecosystem attributes.

\section{METHODS}

\section{Study Sites and Sampling Design}

The two forest sites chosen for this study were located in Vinton and Lawrence Counties of southern Ohio (Figure 1). The sites were contiguous blocks of 90 to 120 ha of oak-dominated forests that developed following clear-cutting for charcoal production 100 to 150 years ago. The Vinton County study site, Arch Rock (lat. $39^{\circ} 11^{\prime} \mathrm{N}$, long. $82^{\circ} 22^{\prime} \mathrm{W}$ ) and the Lawrence County study site, Young's Branch (lat. $38^{\circ} 43^{\prime} \mathrm{N}$, long. $82^{\circ} 41^{\prime} \mathrm{N}$ ) were separated by approximately $55 \mathrm{~km}$. The three watershed-scale treatment units within each study area were relatively similar to each other in topographic profile, vegetation, and soils, and there were no indications of disturbance within the last 50 years (Sutherland et al., 2003).

The soils were dominated by alfisols and were predominantly silt loams with particle size distributions that averaged $26 \%$ sand, $61 \%$ silt, and $13 \%$ clay (Boerner and Sutherland, 2003). The climate of the region is cool, temperate, and continental with mean annual temperature and precipitation of $11.3 \mathrm{C}$ and $1024 \mathrm{~mm}$ for Arch Rock and $12.9 \mathrm{C}$ and $1059 \mathrm{~mm}$ for Young's Branch (Sutherland et al., 2003).

Each study site was composed of three contiguous watersheds (or treatment units) ranging in size from 30 to 80 ha. The individual watersheds within each study area were randomly assigned one of three treatments: an unburned control, annual burns for four consecutive years, and periodic burns at four year intervals.
In each study site, the two fire treatment units were burned in April 1996 (fire behavior detailed in Boerner et al., 2000b). Maximum fire temperatures $10 \mathrm{~cm}$ above the forest floor averaged $157 \mathrm{C}$ at Young's Branch and $210 \mathrm{C}$ at Arch Rock. These fires reduced forest floor fine fuel mass by $35-40 \%$ in both sites (Boerner et al., 2000b). The annual burn units were burned again in April of 1997 and 1998.

Previous analysis of the soils of these study areas indicated that soil chemical properties varied significantly between sites, but not among watersheds within sites (Boerner et al., 2003). The soils at Young's Branch had greater TIN, $\mathrm{Ca}^{2+}$, $\mathrm{Mg}^{2+}$, and molar Ca:Al ratio and higher $\mathrm{pH}$ than the soils at Arch Rock.

\section{Field and Laboratory Methods}

At a random point in a mid-slope position on southeast-facing slope in each treatment unit, we established a macroplot measuring $10 \mathrm{~m}$ (along the slope) $\times 5 \mathrm{~m}$ (across the slope) (Figure 2). This plot was oriented with its long axis along the slope so that we explicitly test for slope position effects even at this small spatial scale. The $50 \mathrm{~m}^{2}$ macroplot was gridded on a $1 \mathrm{~m} \mathrm{X} 1$ $\mathrm{m}$ scale. Then one of the $1 \mathrm{~m}^{2}$ squares defined by that grid was randomly selected for sampling at the microplot scale. The 1 $\mathrm{m}^{2}$ microplot was subdivided into a $25 \mathrm{~cm}$ $\mathrm{X} 25 \mathrm{~cm}$ grid (Figure 2).

In each macroplot and microplot, the coverage of all woody stems, exposed rocks, and coarse woody debris $>5 \mathrm{~cm}$ diameter was mapped. Three core samples (each $2.5 \mathrm{~cm}$ diameter and $10 \mathrm{~cm}$ depth) of $\mathrm{O}_{\mathrm{a}}+\mathrm{A}$-horizon soil were taken at alternating grid points in each macroplot $(\mathrm{N}=33)$ and at each grid point in each microplot $(\mathrm{N}=25)$. The soil samples were returned to the laboratory under refrigeration. 
Figure 1. Map of physiographic provinces of Ohio, with study sites indicated by stars.

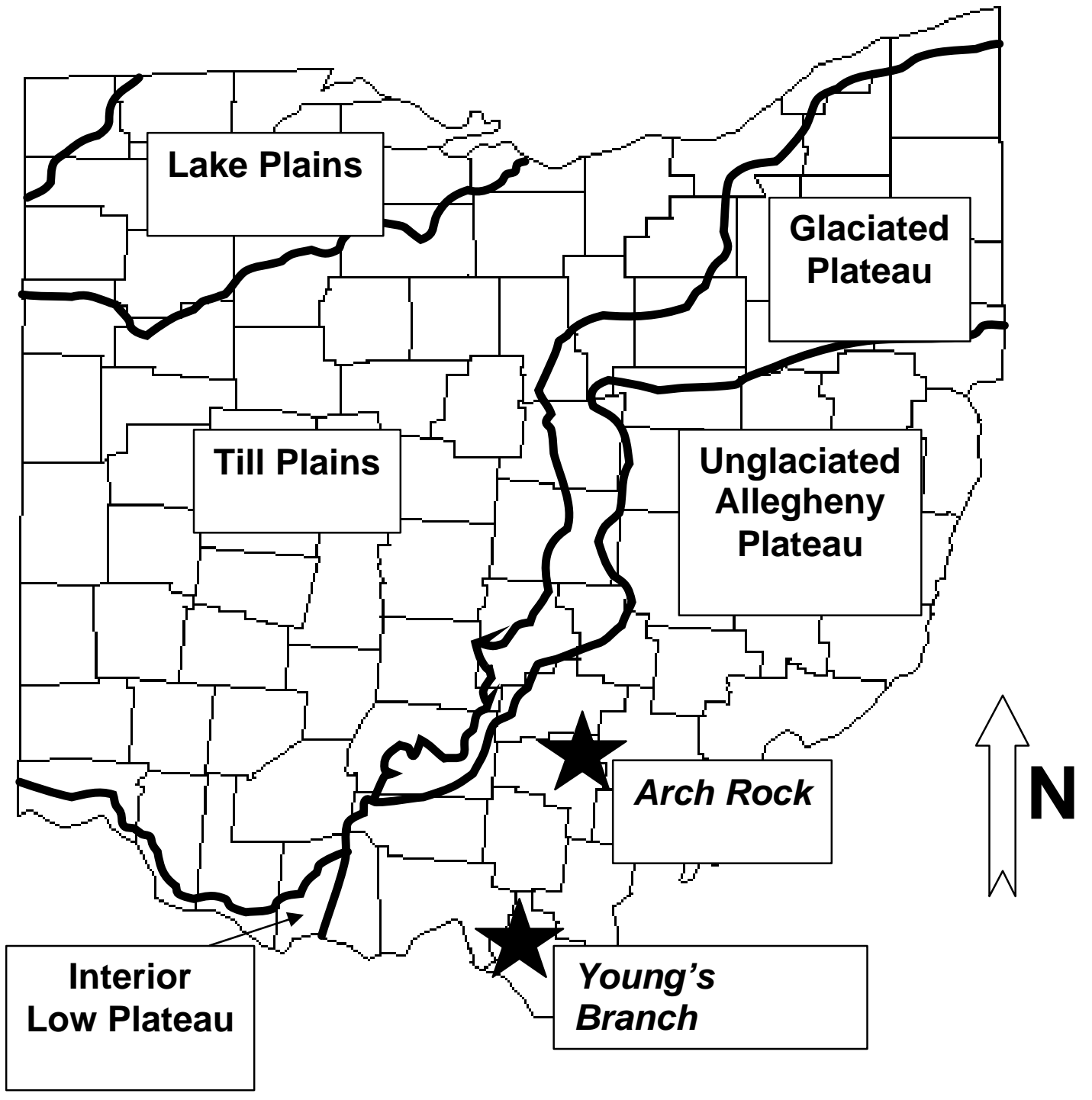


Figure 2. Macroplot and microplot sampling design for assessing spatial autocorrelation in two Ohio forests. Points where samples were taken are indicated by filled circles.

\section{Macroplot \\ $10 \times 5 \mathrm{~m}$ \\ 33 samples}

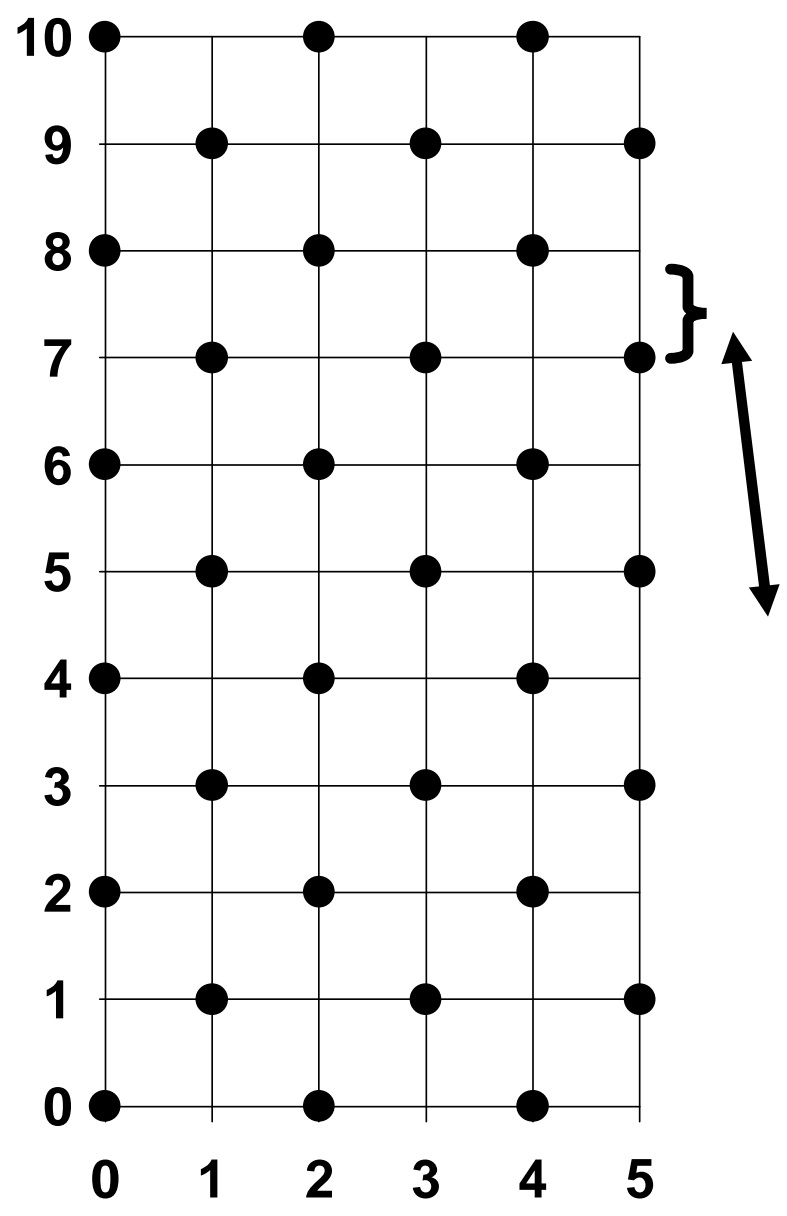

Microplot

$1 \times 1 \mathrm{~m}$, 23 samples

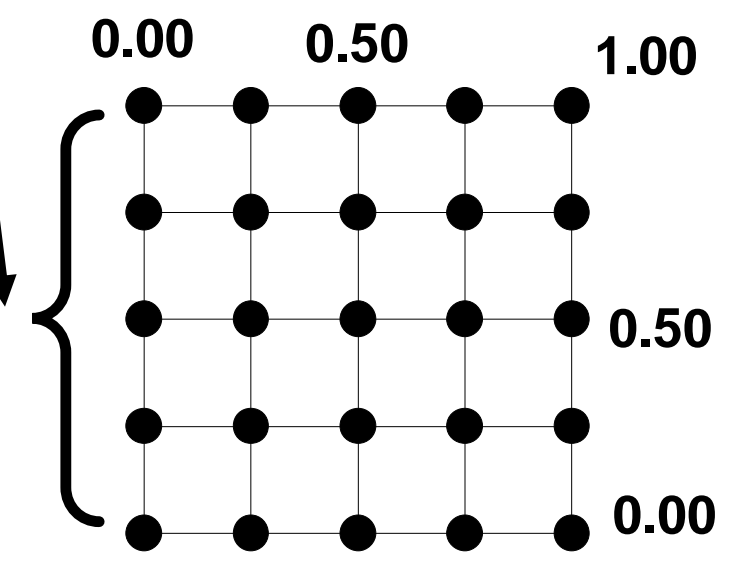


A subsample of approximately $15 \mathrm{~g}$ was extracted with $2 \mathrm{M} \mathrm{KCl}$ and analyzed for $\mathrm{NH}_{4}{ }^{+}$and $\mathrm{NO}_{3}{ }^{-}$using colorimetric methods on a Lachat Quik Chem autoanalyzer. Total inorganic $\mathrm{N}$ (TIN) was calculated as the sum of $\mathrm{NH}_{4}{ }^{+}$and $\mathrm{NO}_{3}{ }^{-}$. Soil organic $\mathrm{C}$ content was determined using WalkleyBlack oxidation (Page et al. 1982) using a conversion factor established empirically for these sites.

Subsamples of approximately $40 \mathrm{~g}$ were placed in incubation chambers and brought to $70 \%$ of field moisture capacity. The incubating samples were maintained at $50-70 \%$ of field capacity for approximately 25 days by weighing each sample every 3-4 days and adding sufficient deionized water to return the moisture to approximately $70 \%$ of field capacity (Morris and Boerner, 1998). Laboratory incubations were chosen for use in this study because the manner in which the moisture regime of the incubating samples was maintained mimicked the temporal pattern of soil moisture that are characteristic of the earlyand mid-growing season in the mixed-oak ecosystems of southern Ohio (Morris and Boerner, 1998). At the end of the incubation period, $\mathrm{NH}_{4}{ }^{+}$and $\mathrm{NO}_{3}{ }^{-}$were extracted as described above, and their concentrations used to calculate the net rates of $\mathrm{N}$ mineralization and nitrification.

\section{Data Analysis}

The experiment was designed as a randomized complete block with sites as blocks, each of which contained all three fire treatments. All response variables were normally distributed (PROC UNIVARIATE; Statistical Analysis System, 1995) and differences among fire treatments and plot sizes were analyzed by three-way analysis of variance (PROC GLM; Statistical Analysis System, 1995). The Ryan-Einot-Gabriel-Welsch multiple range test was used to separate means (Statistical Analysis System, 1995).
In any system structured by nonrandom processes, samples taken from locations close together are more likely to be positively correlated than are samples taken farther apart. To quantify the degree of spatial autocorrelation among the samples from each macroplot and microplot, to determine the maximum distance at which samples were significantly correlated (i.e. the size of distinct patches), and to facilitate subsequent mapping we used semivariance analysis and kriging $\left(\mathrm{GS}^{+}\right.$ Version 3.1, Gamma Design Software, Plainwell, MI.). Semivariance analysis calculates an autocorrelation index (semivariance) among groups of pairs of samples separated by given distances (lag distances) and then produces a composite graph of the relationship between the semivariance among samples and the distance between samples (semivariogram). $\mathrm{GS}^{+}$then fits a range of models to the semivariogram by least-squares analysis. From the best fit model for the semivariogram, the total variance among the samples from a given plot can be divided into one component related to spatial pattern or structure in the data set (the structural variance, C) and a second component which combines variance due to spatially-dependent properties operating at scales smaller than those encompassed by the sampling design plus variance due to sampling/analysis error (the nugget variance, $\mathrm{C}_{\mathrm{o}}$ ). We used the proportion of total model variance $\left(\mathrm{C}+\mathrm{C}_{\mathrm{o}}\right)$ represented by structural variance $(\mathrm{C})$ as a measure of spatial dependence (Robertson and Freckman, 1995). The limits of resolution for this study were $0.25 \mathrm{~m}$ (microplot lower limit) and $7.78 \mathrm{~m}(80 \%$ of the largest macroplot lag distance). 


\section{RESULTS}

\section{Fire Frequency Effects}

Three-way analysis of variance revealed significant overall effects of the fire treatments on net $\mathrm{N}$ mineralization and nitrification rates, but not on TIN or soil organic $\mathrm{C}$ (Table 1). $\mathrm{N}$ mineralization increased with increasing fire frequency, with the soils in the annual fire units averaging $71 \%$ greater $\mathrm{N}$ mineralization than those from control units (Figure 3). There was positive net nitrification in soils from the annual fire units whereas soils in the control and periodic fire units exhibited net immobilization of $\mathrm{NO}_{3}{ }^{-} \mathrm{N}$.

Although the variance associated with plot size was not significant, there were significant interactions between plot size and fire treatment in determining net nitrification and total inorganic $\mathrm{N}$ in the soil solution (Table 1). At the macroplot scale, total inorganic $\mathrm{N}$ was greatest in the annual fire treatment whereas at the microscale it was greatest in the control (Figure 4). The interaction of plot size and fire treatment in affecting net nitrification rate was subtle. Although the overall pattern of net nitifrication in the annual fire treatment and net $\mathrm{NO}_{3}{ }^{-} \mathrm{N}$ immobilization in the periodic fire and control treatments was present at both the macroplot and microplot scale, the control and annual fire treatments differed significantly at the microplot scale but not the macroplot scale (Figure 4).

To more fully explore the interactions among plot size, fire treatment, and block (forest site), we then performed two way analyses of variance separately for each plot size, with fire treatment and block as the main effects (Table 2). Fire treatment significantly affected TIN, N mineralization, and net nitrification in both macroplots and microplots, whereas soil organic $\mathrm{C}$ was not significantly affected by fire treatment at either plot scale (Table 2). Complicating the interpretation of these results were significant block effects and fire treatment-by-block interactions for most response variables at both plot scales (Table 2). Resolution of the interactions of forest site with treatment and plot size requires an experimental design with greater replication than was available in this study.

\section{Plot Size and Spatial Structure}

Significant regression models of TIN could be constructed for the semivariancelag distance relationships in ten of the twelve combinations of plot size, fire treatment, and block (Table 3). At the macroplot scale,

spatial structure accounted for at least $65 \%$ of the total variance among samples in all macroplots except the Arch Rock control. At Arch Rock the scale at which samples continue to be spatially autocorrelated was greater than the maximum that could be resolved by our sampling design, whereas at Young's Branch, spatial autocorrelation was limited to distances of $<6.0 \mathrm{~m}$ (Table 3).

At the microplot scale spatial structure in TIN was more variable among treatments and blocks, with structure varying from $\sim 20 \%$ to $>95 \%$ (Table 3, Figure 5). In three of the microplots spatial autocorrelation limits were greater than could be resolved at this scale, whereas in the other three the distance limit for spatial autocorrelation ranged from 0.16 to $0.68 \mathrm{~m}$ (Table 3). The spatial patterns of TIN confirmed the variations among fire treatments suggested by the analyses of variance.

Semivariance analysis of $\mathrm{N}$ mineralization rates demonstrated significant spatial autocorrelation in all combinations of plot size, fire treatment, and block (Table 3). In only four of the twelve combinations was spatial structure $<50 \%$ of the total variance, and three of those four were from the annual fire treatment (Table 3, Figure 6). The only 
combinations for which our sampling design was adequate to resolve the limits of spatial autocorrelations were the periodic fire macroplots $(0.9-1.4 \mathrm{~m})$ and the control microplots (0.3-0.5 m) (Table 3, Figure 6).

Semivariance analysis of net nitrification rates produced results similar to those for $\mathrm{N}$ mineralization: spatial structure $>50 \%$ for eight of twelve plots and resolution of the limit to spatial autocorrelation in four of twelve plots (Table 3, Figure 7). As was the case for $\mathrm{N}$ mineralization, the only macroplots for which spatial autocorrelation limits could be determined were those from the annual burn plots; in contrast, at the microplot scale, spatial autocorrelation in one control plot and one periodic fire plot were resolvable.

The spatial structure in soil organic $\mathrm{C}$ content was $\geq 55 \%$ (mean $>75 \%$ ) in six of the combinations of plot size, fire treatment, and block and was $\leq 27 \%$ (mean $23 \%$ ) in the remaining six (Table 3 , Figure 8). In general, the scale at which spatial autocorrelation in soil organic $\mathrm{C}$ operated was greater than what we could resolve with our sampling design; however, in three of the twelve plots the limit was $<1.4$ m (Table 3, Figure 8).

\section{DISCUSSION}

Our first objective was to determine how organic $\mathrm{C}$ storage and organic $\mathrm{N}$ turnover, both key ecosystem processes, were affected by fire at two frequencies in this historically N-limited ecosystem (Aber et al., 1989). The $\mathrm{N}$ mineralization rates of soils of our annually and periodically burned plots were approximately $70 \%$ and $20 \%$ greater, respectively, than those of the unburned controls. It is common to such increases in $\mathrm{N}$ mineralization rate and/or TIN in response to fire in many ecosystem types. For example, fire-induced increases in TIN and/or $\mathrm{N}$ mineralization have been reported in Pinus ponderosa forests in western North America (Wagle and
Kitchen, 1972), mixed pine ( $P$. echinata and P. taeda) forests in east Texas (Webb et al., 1971) and California chaparral (Debano et al., 1979).

The soils of the frequently burned units exhibited net nitrification while those from the periodic fire units and controls immobilized $\mathrm{NO}_{3}{ }^{-}$. Neither soil organic $\mathrm{C}$ content nor total inorganic $\mathrm{N}$ (TIN) in the soil solution was affected by fire at either frequency. In contrast to $\mathrm{N}$ mineralization, the nitrification and TIN results were not consistent with the majority of existing fire research. For example, the meta-analysis of the effects of fire on $\mathrm{N}$ cycling done by Wan et al. (2001) concluded that post-fire increases in $\mathrm{NO}_{3}{ }^{-}$are common, and the $\left[\mathrm{NO}_{3}{ }^{-}\right]$peaks approximately one year after fire.

Caution must be exercised in extrapolating the effects of a single fire to those of multiple fires over time. Vance and Henderson (1984) found that annual burning over 30 years reduced $\mathrm{N}$ mineralization and TIN to a greater extent than did periodic burns over the same period. We also found that the initial effects of the first burn in these two study sites (measured one month postfire) differed considerably from what we observed three years later, even in the treatment units burned only once (Boerner and Brinkman, 2004a).

Our second objective was to determine the degree to which these ecosystem properties and processes were spatially autocorrelated and at what maximum distance such spatial autocorrelation existed. The maximum range of spatial autocorrelation essentially establishes the size of non-random patches of resources on the forest floor. Our $50 \mathrm{~m}^{2}$ macroplots permitted estimation of spatial autocorrelation at ranges from approximately $1.0 \mathrm{~m}$ to $7.8 \mathrm{~m}$, and only in approximately $1 / 3$ of the site-by-fire treatment combinations were we able to demonstrate significant spatial autocorrelation in $\mathrm{N}$ turnover within this 
range of spatial scales; of those we could resolve, almost all were in recently burned plots.

Our $1 \mathrm{~m}^{2}$ microplots permitted estimation at ranges from $20 \mathrm{~cm}$ to $80 \mathrm{~cm}$, and once again we observed significant spatial autocorrelation in $\mathrm{N}$ turnover in only approximately $1 / 3$ of the possible cases. Of those, five of seven $(71 \%)$ were from the Young's Branch study site, and four of seven (57\%) were from unburned control units. Thus, in contrast to what we observed for the larger, 1-8 $\mathrm{m}$ patches, most of the discernable patches $<1 \mathrm{~m}$ were in unburned plots.

Spatial dependency in soil biological, chemical, and biochemical properties at a range of nested scales seems to be a common observation in the literature (review by Ettema and Wardle, 2002). However, in few cases have the range of scales and their interrelations been empirically estimated. In sites similar to ours, spatial structure at ranges $<1 \mathrm{~m}$ have been documented for fungal and bacterial biomass (Morris, 1999), mycorrhizal fungal infectivity (Boerner et al., 1996), and $\mathrm{N}$ mineralization (Boerner and Koslowsky, 1989, Bruckner et al., 1999). Other studies have demonstrated spatial structure at ranges between 1 and $10 \mathrm{~m}$, though most have employed sampling designs that precluded quantification at scales <1 m (e.g. Robertson, 1987; Boerner et al., 1998). Other studies yet demonstrate spatial structure at ranges $>10 \mathrm{~m}$, including many which clearly document spatial structure in soil properties that correlate with landscape geomorphic features (e.g. Rahman et al., 1996; Boerner and Brinkman, 2004b).

The results of this study suggest that relatively little spatial structure in soil organic $\mathrm{C}$ and $\mathrm{N}$ turnover exists in our study sites over the range of $0.2 \mathrm{~m}$ to 7.8 $\mathrm{m}$. As strong spatial structure at ranges of $<0.2 \mathrm{~m}$ (e.g. Morris 1999) and > $7.8 \mathrm{~m}$ (e.g. Boerner and Brinkman, 2004b) have already been established in these and nearby study sites, we believe we have now with some certainty established quantitatively the range of nested, hierarchic scales at which these and similar ecosystem processes are structured. Our next challenge is to link this hierarchic pattern of patches in soil properties with vegetation properties that are important to longer term management, especially the diversity of the understory flora, the population dynamics of threatened and endangered plant species, and the abundance and survivorship of tree seedlings.

Our third objective addressed the relationship between sample plot size (in this case $1 \mathrm{~m}^{2}$ vs. $50 \mathrm{~m}^{2}$ ) and judgments about the magnitude, significance, and possible importance of fire effects. In the analysis of variance of the full experiment, plot size was not a significant source of variation for any of the four soil response variables we measured. Pairwise $t$-tests of responses between plots sizes within individual combinations of fire treatment and response variable also demonstrated no significant effect of plot size. Overall, this suggests that estimates in these study sites derived from intensive sampling of small plots (25 samples within $1 \mathrm{~m}^{2}$ ) could be scaled up to $50 \mathrm{~m}^{2}$ with confidence. It does not necessarily follow from this, however, that such extrapolation would still be reliable if the sampling intensity within the $1 \mathrm{~m}^{2}$ plot were reduced greatly.

Several authors (e.g. Bonnicksen and Stone, 1982) have suggested that fire suppression tends reduce spatial heterogeneity in western mixed conifer forests, and Raison (1979) concludes from an exhaustive review that fire tends to increase the spatial heterogeneity of soil resources, especially N. This led us to hypothesize suggest that fire suppression should lead to the loss of spatial structure dominated by small patches in the ecosystems we studied as well. In support of this hypothesis, at our macroplot scale significant patchiness at the $1.0-7.8 \mathrm{~m}$ 
scale could be quantified only in recently burned areas. However, to conclude from this study that this might be a general trend in hardwood forests would not be justifiable given the relatively small number of sites, treatment units, and sample plots analyzed.

Future research should address the mechanism(s) that underlay this change in spatial structure, if indeed such a relationship between fire and patchiness exists in other forested ecosystem types. In our region with fire suppression comes an increase in understory biomass and stem density. These changes can, in turn, could be expected to reduce the heterogeneity of the forest floor through an increase in fine root biomass (Dress and Boerner, 2001). Increases in understory woody stem density would also be expected to reduce patchiness through reductions in autumn and winter leaf litter redistribution, a major mechanism for generating spatial heterogeneity in these landscapes (Boerner and Kooser, 1989). Increasing fire frequency, in contrast, results in a more open understory, akin to that described by early settlers and surveyors (Whitney, 1994) and a much more spatially heterogeneous stem distribution. We suggest this fire-induced increase in above- ground spatial heterogeneity may translate to differences in $\mathrm{C}$ storage and $\mathrm{N}$ turnover in the forest floor and soil, and we urge others to test this hypothesis in a broader range of forested ecosystem.

Studies of presettlement forest structure suggest that frequent, low intensity fires tended to produce and maintain high diversity and high spatial heterogeneity. Thus, fire suppression may result in increasing homogeneity. Just as increasing patch size and coarse-grained structure may serve as an indicator of desertification in desert grasslands, firesuppression induced changes in spatial structure may signal the onset of negative impacts on deciduous forest ecosystems.

\section{ACKNOWLEDGEMENTS}

This research was supported by a USDA Forest Service Ecosystem Management Grant to Elaine Kennedy Sutherland. We thank Melissa Knorr, Bill Dress, Rachel Thiet, Amy Scherzer, and Bob Long for field and laboratory assistance. We thank Carla Giai, Jianjun Huang, Aditi Shenoy, and two anonymous reviewers for comments on earlier drafts of this manuscript. 


\section{REFERENCES}

Aber, J.D., K.J. Nadelhoffer, P. Steudler, and J. Melillo. "Nitrogen Saturation in Northern Forest Ecosystems." BioScience 39 (1989): 378-386.

Boerner, R.E.J. "Effects of Fire on the Ecology of the Forest Floor and Soil of Central Hardwood Forests." In Proceedings, Conference on Fire, People, and the Central Hardwood Landscape, edited by D.A. Yaussy, 56-63. Newtown Square, PA: U.S.D.A. Forest Service Northeast Research Station, 2000.

Boerner, R.E.J. and J.A. Brinkman. "Effects of Fire at Two Frequencies on Nitrogen Transformations and Soil Chemistry in a Nitrogen-enriched Forest Landscape." Canadian Journal of Forest Research 34 (2004a): 609-618.

Boerner, R.E.J. and J.A. Brinkman. "Spatial, Temporal, and Restoration Treatment Effects on Soil Resources in Mixed-oak Forests of Southeastern Ohio." In Proceedings of the $14^{\text {th }}$ Central Hardwood Forest Conference, edited by D.A. Yaussy, 241-254. Newtown Square, PA: USDA Forest Service Northeast Research Station, 2004b.

Boerner, R.E.J. and J.G. Kooser. "Leaf Litter Redistribution Among Forest Patches Within an Allegheny Plateau Watershed.” Landscape Ecology 2 (1989): 81-92.

Boerner, R.E.J. and S.D. Koslowsky. "Microscale Variations in Nitrogen Mineralization and Nitrification in a Beech-maple Forest." Soil Biology and Biochemistry 21 (1989): 795-801.

Boerner, R.E.J. and E. Kennedy. Sutherland. "Physiography, Geology and Soil Classification.” In Characteristics of Mixed Oak Forest Ecosystems in Southern Ohio Prior to the Reintroduction of Fire, edited by E. Kennedy Sutherland and T.F. Hutchinson, 43-46. Newtown Square PA: U.S.D.A. Forest Service Northeastern Research Station, 2003.

Boerner, R.E.J., B.G. DeMars, and P.N. Leicht. "Spatial Patterns of Mycorrhizal Infectiveness of Soils Along a Successional Chronosequence.” Mycorrhiza 6 (1996): 79-90.

Boerner, R.E.J., A.J. Scherzer, and J.A. Brinkman. Spatial Patterns of Inorganic N, P Availability, and Organic C in Relation to Soil Disturbance: A Chronosequence Analysis." Applied Soil Ecology 7 (1998): 159-177.

Boerner, R.E.J., S.J. Morris, K.L.M. Decker, and T.F. Hutchinson. Soil and Forest Floor Chemical and Physical Characteristics. In Characteristics of Mixed Oak Forest Ecosystems in Southern Ohio Prior to the Reintroduction of Fire, edited by E. Kennedy Sutherland and T.F. Hutchinson, 47-56. Newtown Square PA: U.S.D.A. Forest Service Northeastern Research Station, 2003.

Boerner, R.E.J., K.L.M. Decker, and E. Kennedy Sutherland. "Prescribed Burning Effects on Soil Enzyme Activity in a Southern Ohio Hardwood Forest: A Landscape Scale Analysis.” Soil Biology and Biochemistry 32 (2000a): 899-908. 
Boerner, R.E.J., E. Kennedy Sutherland, S. Jeakins Morris, and T.F. Hutchinson. "Spatial Variations in the Effect of Prescribed Fire on N Dynamics in a Forested Landscape." Landscape Ecology 15 (2000b): 425-439.

Bonnicksen, T.M. and E.C. Stone. "Reconstruction of a Presettlement Giant Sequioa-Mixed Conifer Forest Community Using the Aggregation Approach.” Ecology 63 (1982): 11341148.

Bruckner, A.; E. Kandeler, and C. Kampichler. Plot-scale Spatial Patterns of Soil Water Content, $\mathrm{pH}$, Substrate-induced Respiration and N Mineralization in a Temperate Coniferous Forest." Geoderma 93 (1999): 207-223.

Crozier, C.R., and R.E.J. Boerner. "Correlations of Understory Herb Distribution with Microhabitats Under Different Tree Species in a Mixed Mesophytic Forest. Oecologia 62 (1984): 337-343.

Debano, L.F., G.E. Eberlein, and D.H. Dunn. "Effects of Burning on Chaparral Soils: I. Soil Nitrogen.” Soil Science Society of America Journal 43 (1979): 504-509.

Decker, K.L.M, R.E.J. Boerner, and S. J. Morris. 1999. "Scale-dependent Patterns of Soil Enzyme Activity in a Forested Landscape. Canadian Journal of Forest Research 29 (1999): 232241.

Dress, W.J. and R.E.J. Boerner. "Root Biomass and Production in Relation to Fire Frequency and Landscape Position in Ohio Oak-hickory Forests." Canadian Journal of Forest Research 31 (2001): 644-653.

Ettema, C.H. and D.A. Wardle. "Spatial Soil Ecology." Trends in Ecology and Evolution 17 (2002): 177-183.

Guyette, R.P. and B.E. Cutter. "Tree-ring Analysis of Fire History of a Post Oak Savanna in the Missouri Ozarks. Natural Areas Journal 111 (1991): 93-99.

Hutchinson, T.F., R.E.J. Boerner, L.R. Iverson, and S. Sutherland. "Landscape Patterns of Understory Composition and Richness Across a Moisture and Nitrogen Mineralization Gradient in Ohio (U.S.A.) Quercus Forests." Plant Ecology 144 (1999): 179-189.

Morris, S.J. "Spatial Distribution of Fungal and Bacterial Biomass in Southern Ohio Hardwood Forest Soils: Fine Scale Variability and Microscale Patterns." Soil Biology and Biochemistry 31 (1999): 1375-1386.

Morris, S.J. and R.E.J. Boerner. "Landscape Patterns of Nitrogen Mineralization and Nitrification in Southern Ohio Hardwood Forests.” Landscape Ecology 13 (1998): 215-224. 
Morris, S.J. and R.E.J. Boerner. "Spatial Distribution of Fungal and Bacterial Biomass in Southern Ohio Hardwood Forest Soils: Scale Dependency and Landscape Patterns.” Soil Biology and Biochemistry 31 (1999): 887-902.

Page, A.L., R.H. Miller, and D.R. Keeney. Methods of Soil Analysis, Part 2: Chemical and Microbiological Properties, $2^{\text {nd }}$ edition. Madison, WI: American Society for Agronomy, 1982.

Rahman, S.; L.C. Munn, R. Zhang, and G.F. Vance. "Rocky Mountain Forest Soils: Evaluating Spatial Variability Using Conventional Statistics and Geostatistics." Canadian Journal of Soil Science 76 (1996): 501-507.

Raison, R.J. "Modification of the Soil Environment by Vegetation Fires, With Particular Reference to Nitrogen Transformations: A Review." Plant and Soil 51 (1979): 73-108.

Robertson, G.P. “Geostatistics in Ecology: Interpolating With Known Variance.” Ecology 68 (1987): 744-748.

Robertson, G.P. and D.W. Freckman. “The Spatial Distribution of Nematode Trophic Groups Across a Cultivated Ecosystem. Ecology 76 (1995): 1425-1432.

Statistical Analysis System. SAS User's Guide, Version 6.0. Cary, NC: SAS Institute, 1995.

Sutherland, E. Kennedy. "History of Fire in a Southern Ohio Second-growth Mixed-oak Forest." In Proceedings of the $11^{\text {th }}$ Central Hardwood Forest Conference, edited by S.G. Pallardy, R.A. Cecich, H.E. Garrett, and P.S. Johnson, 172-188. Columbia, MO: U.S.D.A. Forest Service North Central Research Station, 1997.

Sutherland, E.K., T. F. Hutchinson, and D.A. Yaussy.. "Introduction, Study Area Description, and Experimental Design." In Characteristics of Mixed Oak Forest Ecosystems in Southern Ohio Prior to the Reintroduction of Fire, edited by E. Kennedy Sutherland and T.F. Hutchinson,1-16. Newtown Square PA: U.S.D.A. Forest Service Northeastern Research Station, 2003.

Vance, E.D. and G.S. Henderson. "Soil Nitrogen Availability Following Long-term Burning in an Oak-hickory Forest.” Soil Science Society of America Journal 48 (1984): 184-190.

Wagle, R.F. and J.H. Kitchen. "Influence of Fire on Soil Nutrients in a Ponderosa Pine Type." Ecology 53 (1972): 118-125.

Wan, S., D. Hui, and Y. Luo. "Fire Effects on Nitrogen Pools and Dynamics in Terrestrial Ecosystems: A Meta-analysis." Ecological Applications 11 (2001): 1349-1365.

Webb, B.G, M.G. Messina, and J.M. Guldin. "Effects of Prescribed Burning and Varying Basal Areas on Nitrogen Mineralization in an East Texas Pine Forest. In Proceedings of the Sixth 
Biennial Southern Silvicultural Research Conference, 418-430. Memphis, TN: Memphis State University Press, 1971.

Wells, C.G. "Effects of Prescribed Burning on Soil Chemical Properties and Nutrient Availabiilty." In Prescribed Burning Symposium Proceedings, Edited by Stephen G. Boyce,86-96. Asheville, NC: U.S.D.A. Forest Service Southeastern Forest Experiment Station, 1971.

Whitney, G.G. From Coastal Wilderness to Fruited Plain: A History of Environmental Change in Temperate North America. NY: Cambridge University Press, 1994.

Wolfe, J.T., R.T. Wareham, and H.T. Scofield. "Microclimates and Macroclimate of Neotoma, A Small Valley in Central Ohio." Ohio Biological Survey Bulletin 41 (1949): 1-267. 


\section{Figures and Tables}

Figure 3. Fire frequency effects on soil $\mathrm{N}$ turnover and organic $\mathrm{C}$ content. Means and standard errors of the means are shown ( $\mathrm{N}=56$ for each bar), and bars labeled with the same lower case letter were not significantly different at $\mathrm{p}<0.05$.

\section{Control}

Periodic Fire

Annual Fire
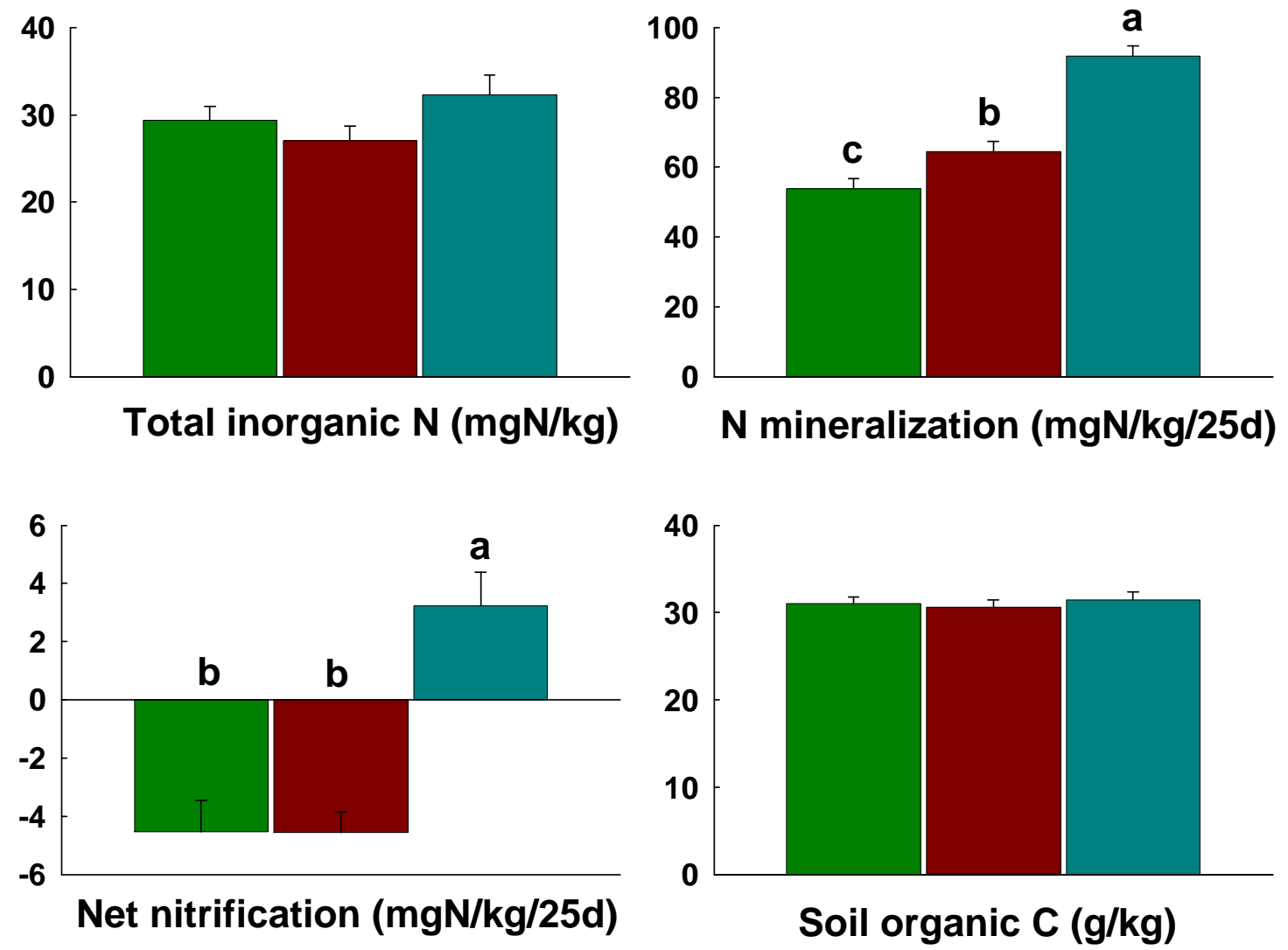
Figure 4. Fire frequency effects on soil $\mathrm{N}$ turnover and organic $\mathrm{C}$ content in relation to sample plot size. Means and standard errors of the means are shown $\left(\mathrm{N}=33\right.$ for each $50 \mathrm{~m}^{2}$ macroplot and $\mathrm{N}=25$ for each $1 \mathrm{~m}^{2}$ microplot), and bars labeled with the same lower case letter were not significantly different at $\mathrm{p}<0.05$.

Control

Periodic Fire

Annual Fire
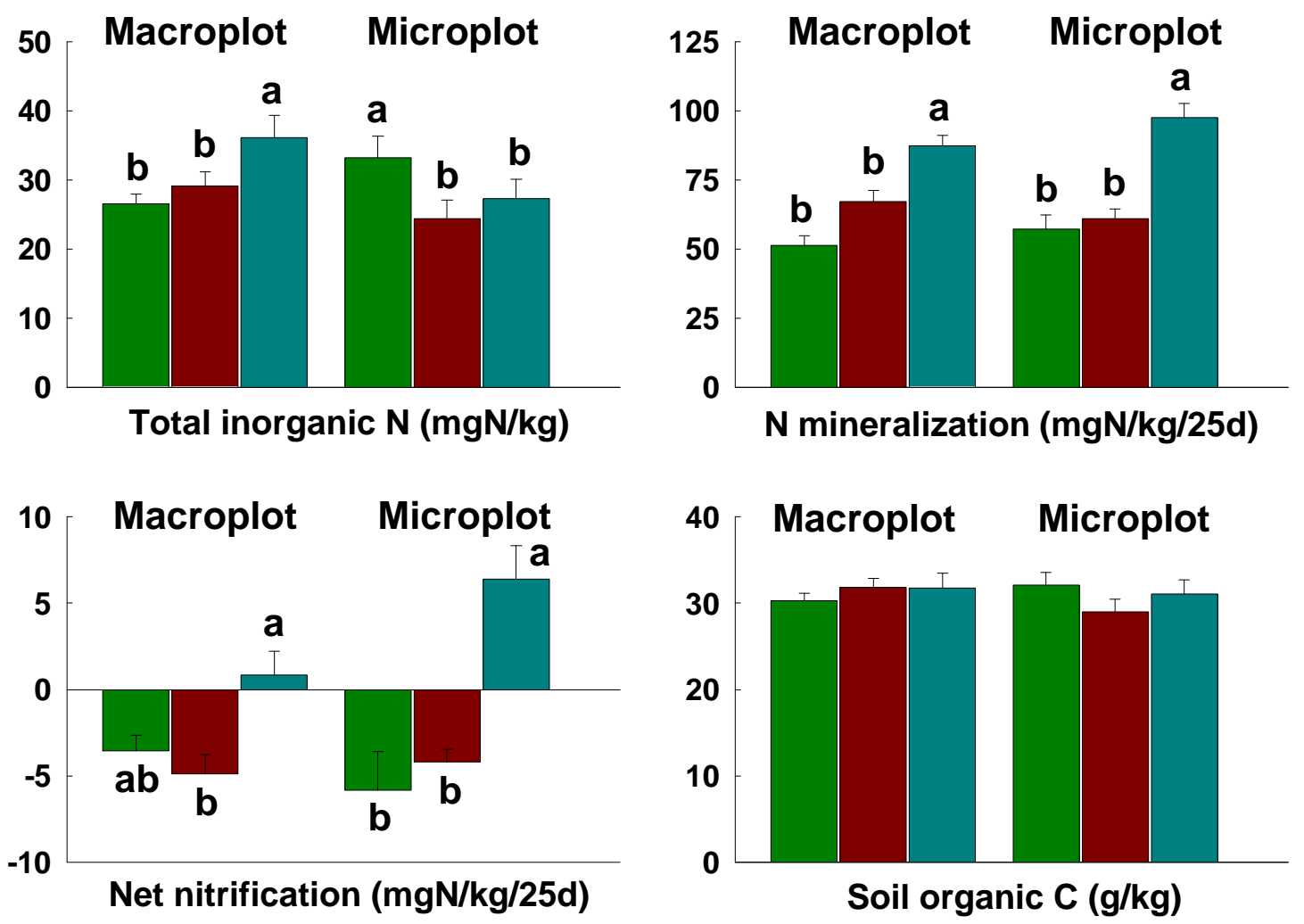
Figure 5. Spatial patterns of total inorganic $\mathrm{N}$ in $50 \mathrm{~m}^{2}$ macroplots and $1 \mathrm{~m}^{2}$ microplots (lower row) in Arch Rock and Young's Branch, $\mathrm{OH}$.

\section{Total Inorganic N (TIN)}

\section{Macroplots}
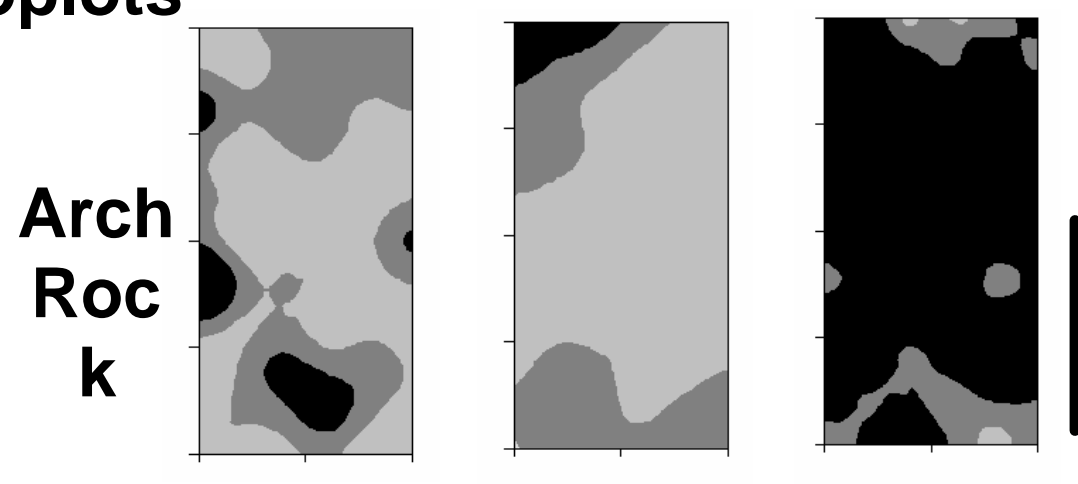

$5.0 \mathrm{~m}$
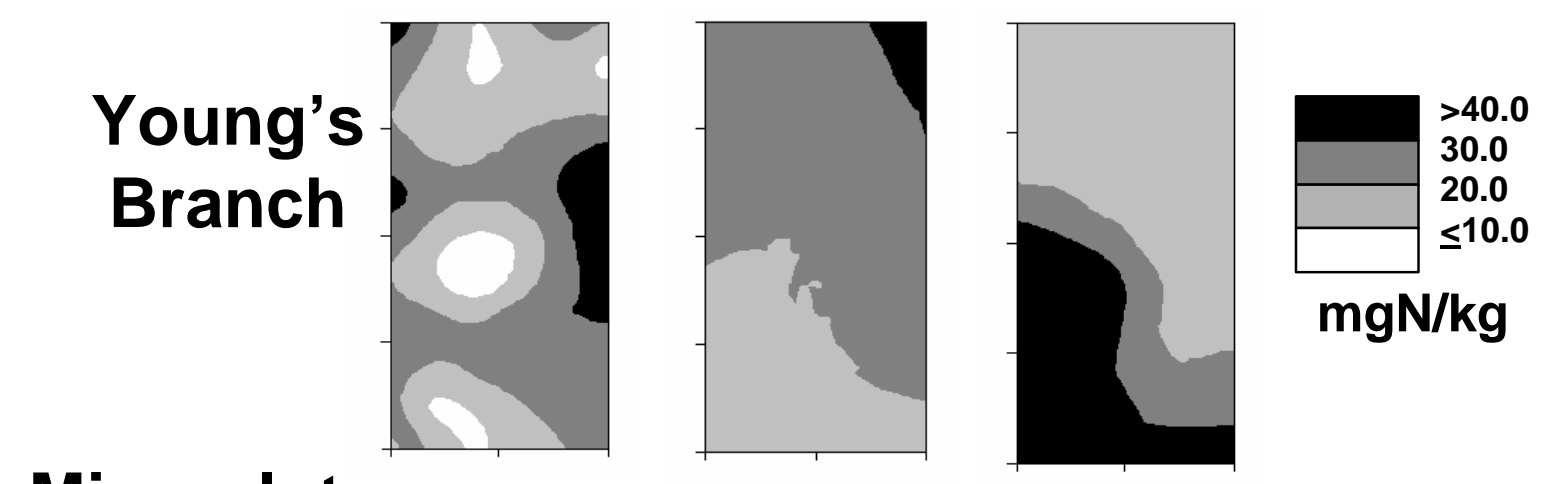

$\mathrm{mgN} / \mathrm{kg}$
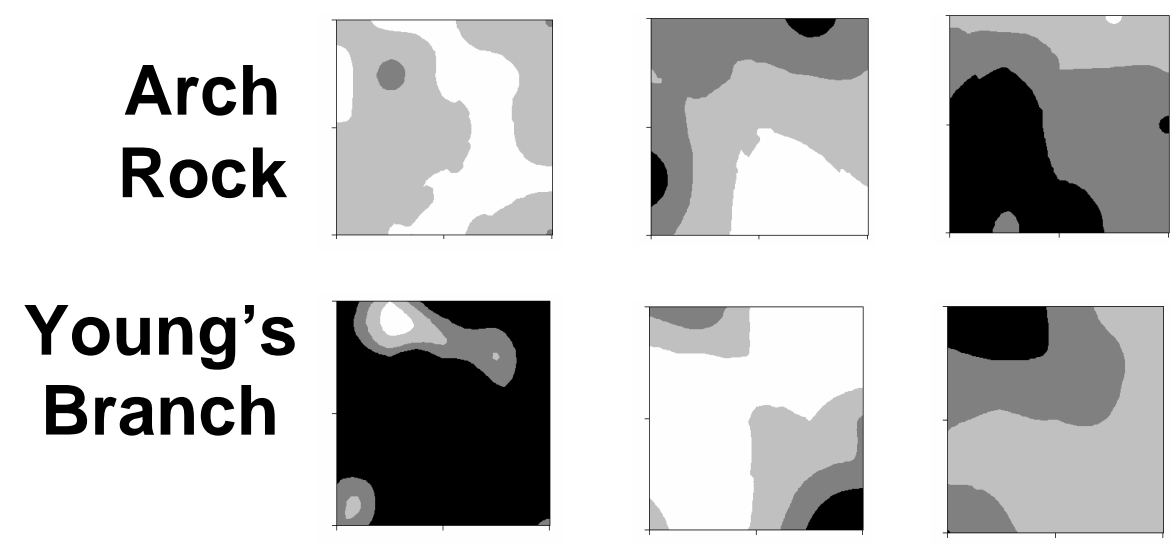

Control
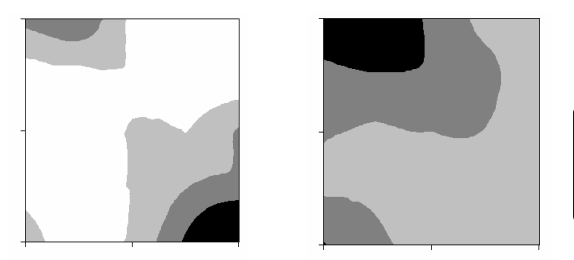

$0.5 \mathrm{~m}$
Periodic Annual

Fire
Fire 
Figure 6. Spatial patterns of $\mathrm{N}$ mineralization rate in $50 \mathrm{~m}^{2}$ macroplots and $1 \mathrm{~m}^{2}$ microplots in Arch Rock and Young's Branch, $\mathrm{OH}$.

\section{Macroplots}

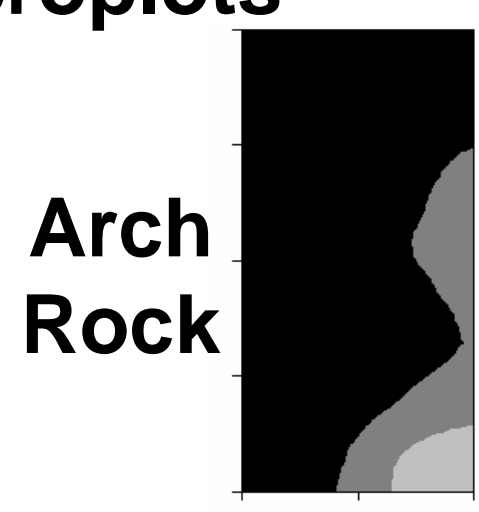

N Mineralization
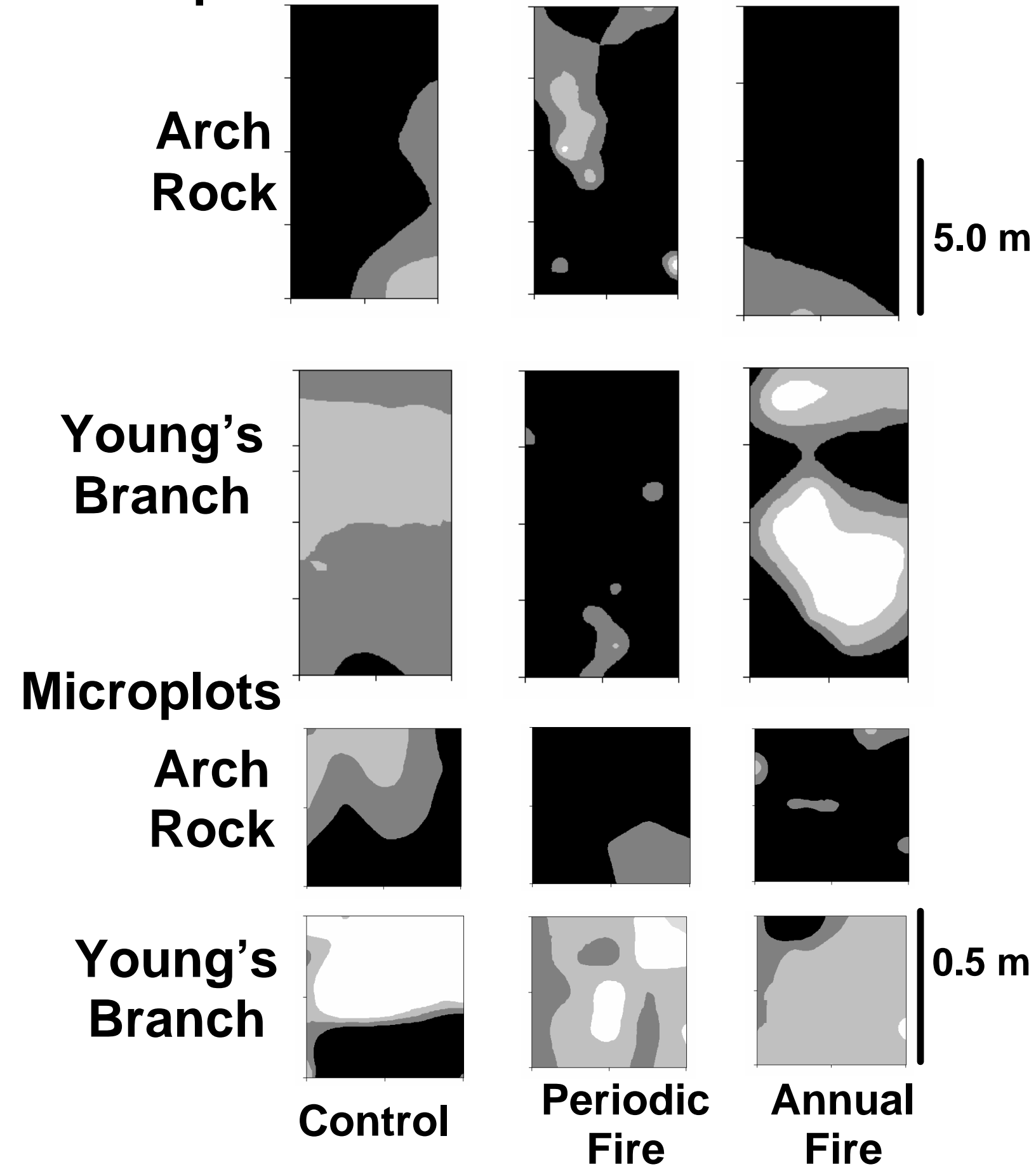
Figure 7. Spatial patterns of net nitrification in $50 \mathrm{~m}^{2}$ macroplots and $1 \mathrm{~m}^{2}$ microplots in Arch Rock and Young's Branch, $\mathrm{OH}$.

\section{Macroplots Net Nitrification}

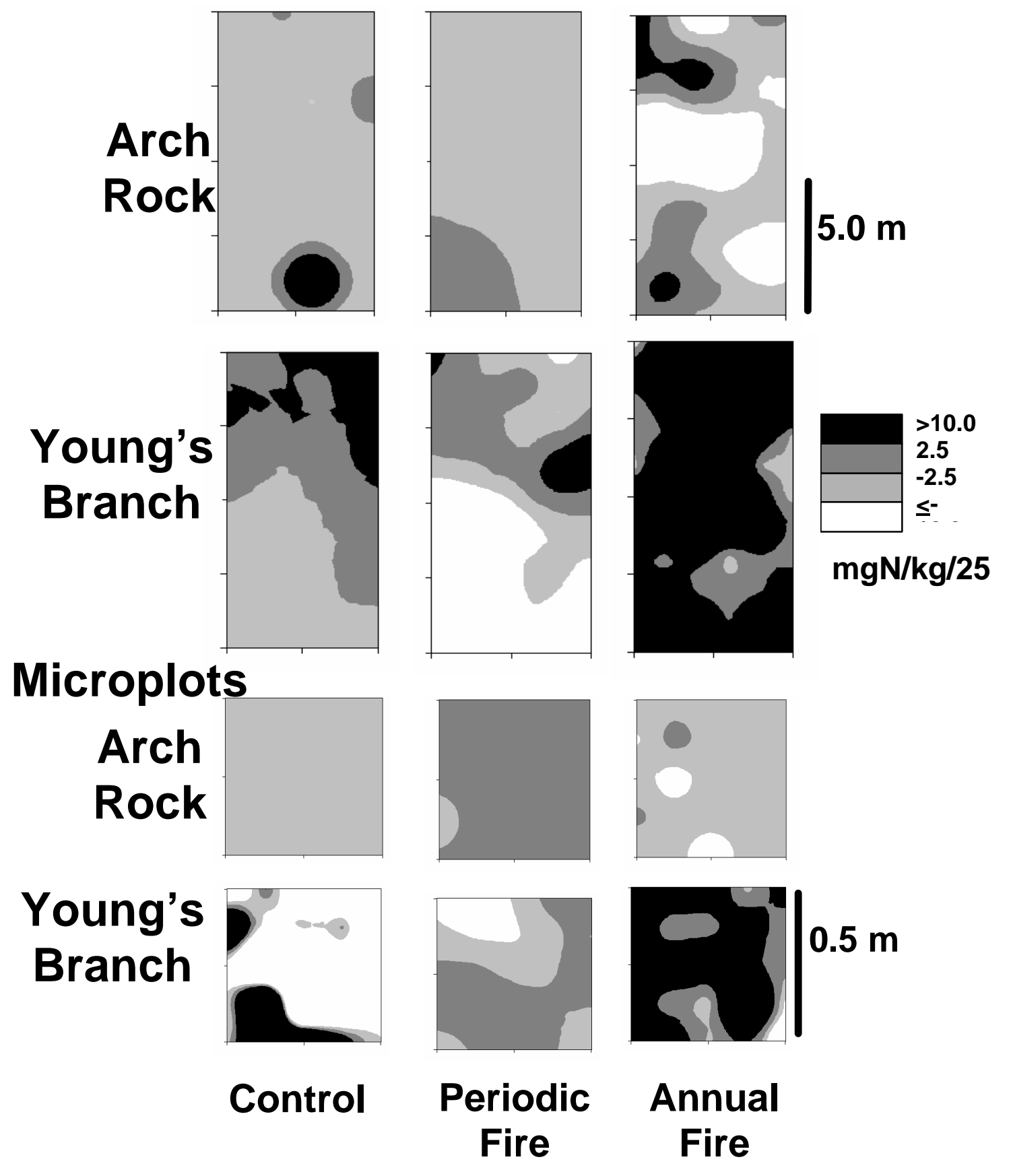


Figure 8. Spatial patterns of soil organic $\mathrm{C}$ in $50 \mathrm{~m}^{2}$ macroplots and $1 \mathrm{~m}^{2}$ microplots in Arch Rock and Young's Branch, $\mathrm{OH}$.

\section{Macroplots}

\section{Soil Organic C}

Arch Rock
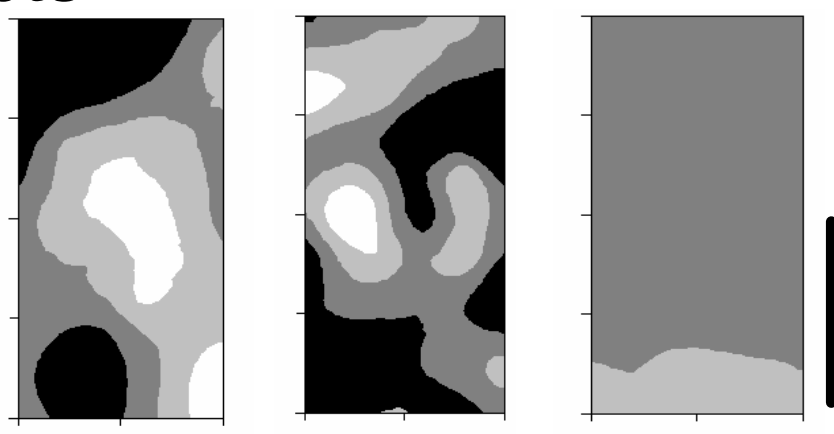

$5.0 \mathrm{~m}$

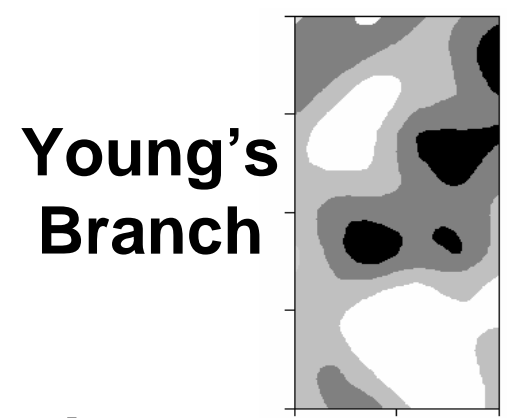

\section{Microplots}
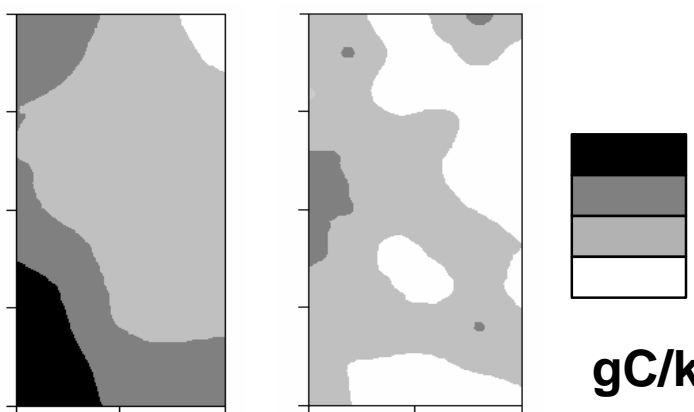

$>35.0$

30.0

25.0

$\leq 20.0$

$\mathrm{gC} / \mathrm{k}$

g
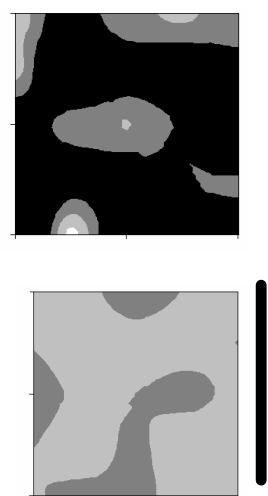

$0.5 \mathrm{~m}$

\section{Young's Branch}

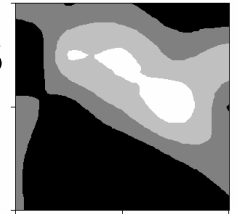

Control
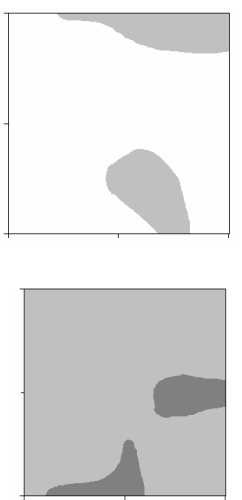

Periodic Fire
Annual

Fire 
Table 1. Three-way Analysis of variance of soil properties in two Ohio mixed-oak forests, with fire treatment, plot size, and study site (=block) as main effects. $\mathrm{N}=376$. Variance components not significant at $\mathrm{p} \leq 0.05$ are indicated in italics.

\begin{tabular}{|c|c|c|c|c|c|c|c|}
\hline $\begin{array}{l}\text { Response } \\
\text { Variable }\end{array}$ & $\begin{array}{l}\text { Full } \\
\text { Model }\end{array}$ & Fire & $\begin{array}{c}\text { Plot } \\
\text { Treatment }\end{array}$ & $\begin{array}{l}\text { Block } \\
\text { Size }\end{array}$ & $\begin{array}{l}\text { Fire-Plot } \\
\text { Interaction }\end{array}$ & $\begin{array}{l}\text { Fire-Block } \\
\text { Interaction }\end{array}$ & $\begin{array}{l}\text { Plot-Block } \\
\text { Interaction }\end{array}$ \\
\hline $\begin{array}{l}\text { Total } \\
\text { Inorganic N }\end{array}$ & $\begin{array}{l}F=10.82 \\
p<0.001\end{array}$ & $\begin{array}{l}F=2.36 \\
p<0.097\end{array}$ & $\begin{array}{l}F=1.38 \\
p<0.241\end{array}$ & & & & $\begin{array}{l}F=9.82 \\
\mathrm{p}<0.002\end{array}$ \\
\hline $\begin{array}{l}\mathrm{N} \\
\text { Mineralization }\end{array}$ & $\begin{array}{l}F=15.63 \\
p<0.001\end{array}$ & $\begin{array}{l}F=50.11 \\
p<0.001\end{array}$ & $\begin{array}{l}F=1.06 \\
p<0.305\end{array}$ & & $\begin{array}{l}F=2.17 \\
p<0.116\end{array}$ & $\begin{array}{l}F=5.56 \\
p<0.005\end{array}$ & $\begin{array}{l}F=1.07 \\
p<0.302\end{array}$ \\
\hline $\begin{array}{l}\text { Net } \mathrm{n} \\
\text { Nitrificatio }\end{array}$ & $\begin{array}{l}F=15.94 \\
p<0.001\end{array}$ & $\begin{array}{l}F=27.62 \\
p<0.001\end{array}$ & $\begin{array}{l}F=1.58 \\
p<0.211\end{array}$ & $\begin{array}{l}F=19.96 \\
p<0.001\end{array}$ & $\begin{array}{l}\mathrm{F}=4.82 \\
\mathrm{p}<0.009\end{array}$ & $\begin{array}{l}F=27.53 \\
p<0.001\end{array}$ & $\begin{array}{l}F=4.59 \\
p<0.033\end{array}$ \\
\hline $\begin{array}{l}\text { Soil } \\
\text { Organic C }\end{array}$ & $\begin{array}{l}F=10.75 \\
p<0.001\end{array}$ & $\begin{array}{l}F=0.44 \\
p<0.648\end{array}$ & $\begin{array}{l}F=0.34 \\
p<0.563\end{array}$ & $\begin{array}{l}F=43.08 \\
p<0.001\end{array}$ & $\begin{array}{l}F=2.09 \\
p<0.125\end{array}$ & $\begin{array}{l}F=23.77 \\
p<0.001\end{array}$ & $\begin{array}{l}F=0.02 \\
p<0.981\end{array}$ \\
\hline
\end{tabular}

Table 2. Two-way analysis of variance of soil properties in two Ohio mixed-oak forests in relation to sample plot size. Macroplots were $50 \mathrm{~m}^{2}$ and microplots were $1 \mathrm{~m}^{2} . \mathrm{N}=198$ for the macroplots and $\mathrm{N}=132$ for the microplots. Variance components not significant at $\mathrm{p} \leq 0.05$ are indicated in italics.

\begin{tabular}{|c|c|c|c|c|}
\hline $\begin{array}{l}\text { Response } \\
\text { Variable } \\
\text { Total Inorganic N }\end{array}$ & Full Model & $\begin{array}{c}\text { Fire } \\
\text { Treatment }\end{array}$ & Block & $\begin{array}{c}\text { Fire-by-Block } \\
\text { Interaction }\end{array}$ \\
\hline \multirow[t]{2}{*}{ Macroplot } & $\mathrm{F}=15.59$ & $\mathrm{~F}=6.21$ & $F=36.95$ & $\mathrm{~F}=14.12$ \\
\hline & $\mathrm{p}<0.001$ & $\mathrm{p}<0.003$ & $\mathrm{p}<0.001$ & $\mathrm{p}<0.001$ \\
\hline \multirow[t]{2}{*}{ Microplot } & $\mathrm{F}=8.23$ & $\mathrm{~F}=3.01$ & $F=0.43$ & $\mathrm{~F}=17.46$ \\
\hline & $\mathrm{p}<0.001$ & $\mathrm{p}<0.050$ & $p<0.514$ & $\mathrm{p}<0.001$ \\
\hline \multicolumn{5}{|l|}{ N Mineralization } \\
\hline \multirow[t]{2}{*}{ Macroplot } & $\mathrm{F}=18.39$ & $\mathrm{~F}=27.53$ & $\mathrm{~F}=21.64$ & $\mathrm{~F}=7.63$ \\
\hline & $\mathrm{p}<0.001$ & $\mathrm{p}<0.001$ & $\mathrm{p}<0.001$ & $\mathrm{p}<0.001$ \\
\hline \multirow[t]{2}{*}{ Microplot } & $\mathrm{F}=12.14$ & $\mathrm{~F}=24.77$ & $\mathrm{~F}=5.26$ & $F=2.97$ \\
\hline & $\mathrm{p}<0.001$ & $\mathrm{p}<0.001$ & $\mathrm{p}<0.024$ & $p<0.055$ \\
\hline \multicolumn{5}{|l|}{ Net Nitrification } \\
\hline \multirow[t]{2}{*}{ Macroplot } & $\mathrm{F}=14.79$ & $\mathrm{~F}=8.92$ & $\mathrm{~F}=35.29$ & $\mathrm{~F}=10.75$ \\
\hline & $\mathrm{p}<0.001$ & $\mathrm{p}<0.002$ & $\mathrm{p}<0.001$ & $\mathrm{p}<0.001$ \\
\hline \multirow[t]{2}{*}{ Microplot } & $\mathrm{F}=14.78$ & $\mathrm{~F}=17.90$ & $\mathrm{~F}=1.84$ & $\mathrm{~F}=18.43$ \\
\hline & $\mathrm{p}<0.001$ & $\mathrm{p}<0.001$ & $\mathrm{p}<0.178$ & $\mathrm{p}<0.001$ \\
\hline \multicolumn{5}{|l|}{ Soil Organic C } \\
\hline \multirow[t]{2}{*}{ Macroplot } & $\mathrm{F}=8.54$ & $F=0.82$ & $\mathrm{~F}=28.83$ & $F=6.04$ \\
\hline & $\mathrm{p}<0.001$ & $p<0.443$ & $\mathrm{p}<0.001$ & $\mathrm{p}<0.003$ \\
\hline \multirow[t]{2}{*}{ Microplot } & $\mathrm{F}=16.86$ & $F=1.71$ & $\mathrm{~F}=18.39$ & $\mathrm{~F}=31.01$ \\
\hline & $\mathrm{p}<0.001$ & $p<0.184$ & $\mathrm{p}<0.001$ & $\mathrm{p}<0.001$ \\
\hline
\end{tabular}


Table 3. Semivariance analysis of soil properties at two spatial scales in Ohio mixed-oak forests. Only regression models significant at $\mathrm{p} \leq 0.05$ are shown; $\mathrm{N}=33$ for $50 \mathrm{~m}^{2}$ macroplots and $\mathrm{N}=23$ for $1 \mathrm{~m}^{2}$ microplots. The proportion of variance attributable to spatial structure is given as the ratio of the structural variance, $\mathrm{C}$, to the total variance $\left(\mathrm{C}+\mathrm{C}_{\mathrm{o}}\right)$. The maximum range of significant spatial autocorrelation is given, with predicted ranges outside of the limits of the sampling design indicated in parentheses.

\begin{tabular}{|c|c|c|c|c|c|c|}
\hline Parameter & $\begin{array}{c}\text { Fire } \\
\text { Frequency }\end{array}$ & $\begin{array}{c}\text { Plot } \\
\text { Size }\left(\mathrm{m}^{2}\right)\end{array}$ & $\begin{array}{c}\text { Spatial } \\
\text { Structure }\end{array}$ & $\begin{array}{l}\text { Range } \\
\text { (m) }\end{array}$ & $\begin{array}{c}\text { Spatial } \\
\text { Structure }\end{array}$ & $\begin{array}{l}\text { Range } \\
\text { (m) }\end{array}$ \\
\hline \multirow{6}{*}{$\begin{array}{l}\text { Total Inorganic N } \\
\text { (mg N/kg soil) }\end{array}$} & control & 50 & $27.1 \%$ & $(>7.78)$ & $65.3 \%$ & $(>7.78)$ \\
\hline & periodic & 50 & $76.7 \%$ & $(>7.78)$ & $81.7 \%$ & 5.83 \\
\hline & annual & 50 & $\mathrm{n} / \mathrm{a}$ & $\mathrm{n} / \mathrm{a}$ & $70.5 \%$ & 2.02 \\
\hline & control & 1 & $21.3 \%$ & $(>0.82)$ & $\mathrm{n} / \mathrm{a}$ & $\mathrm{n} / \mathrm{a}$ \\
\hline & periodic & 1 & $63.0 \%$ & $(>0.82)$ & $72.1 \%$ & 0.68 \\
\hline & annual & 1 & $87.2 \%$ & $(>0.82)$ & $87.2 \%$ & 0.53 \\
\hline \multirow{6}{*}{$\begin{array}{l}\mathrm{N} \text { mineralization } \\
(\mathrm{mg} \mathrm{N} / \mathrm{kg} \text { soil/25 } \mathrm{d})\end{array}$} & control & 50 & $69.7 \%$ & $(>7.78)$ & $59.7 \%$ & $(>7.78)$ \\
\hline & periodic & 50 & $85.4 \%$ & 0.90 & $96.9 \%$ & 1.38 \\
\hline & annual & 50 & $71.5 \%$ & $(>7.78)$ & $27.1 \%$ & $(>7.78)$ \\
\hline & control & 1 & $66.0 \%$ & 0.45 & $89.8 \%$ & 0.26 \\
\hline & periodic & 1 & $72.1 \%$ & $(>0.82)$ & $21.3 \%$ & $(>0.82)$ \\
\hline & annual & 1 & $22.3 \%$ & $(>0.82)$ & $34.2 \%$ & $(>0.82)$ \\
\hline \multirow{6}{*}{$\begin{array}{l}\text { Net nitrification } \\
(\mathrm{mg} \mathrm{N} / \mathrm{kg} \text { soil/25 d) }\end{array}$} & control & 50 & $36.0 \%$ & $(>7.78)$ & $80.8 \%$ & $(>7.78)$ \\
\hline & periodic & 50 & $74.0 \%$ & $(>7.78)$ & $77.6 \%$ & 4.12 \\
\hline & annual & 50 & $77.8 \%$ & 0.85 & $35.4 \%$ & $(>7.78)$ \\
\hline & control & 1 & $85.5 \%$ & 0.81 & $21.3 \%$ & $(>0.82)$ \\
\hline & periodic & 1 & $61.7 \%$ & $(>0.82)$ & $69.8 \%$ & 0.58 \\
\hline & annual & 1 & $21.7 \%$ & $(>0.82)$ & $21.3 \%$ & $(>0.82)$ \\
\hline \multirow{6}{*}{$\begin{array}{l}\text { Soil Organic C } \\
\text { (g C/kg soil) }\end{array}$} & control & 50 & $79.9 \%$ & 1.31 & $27.0 \%$ & $(>7.78)$ \\
\hline & periodic & 50 & $27.0 \%$ & $(>7.78)$ & $55.3 \%$ & $(>7.78)$ \\
\hline & annual & 50 & $69.9 \%$ & $(>7.78)$ & $\mathrm{n} / \mathrm{a}$ & $\mathrm{n} / \mathrm{a}$ \\
\hline & control & 1 & $21.3 \%$ & $(>0.82)$ & $99.9 \%$ & 0.26 \\
\hline & periodic & 1 & $68.8 \%$ & $(>0.82)$ & $21.3 \%$ & $(>0.82)$ \\
\hline & annual & 1 & $\mathrm{n} / \mathrm{a}$ & $\mathrm{n} / \mathrm{a}$ & $21.2 \%$ & $(>0.82)$ \\
\hline
\end{tabular}

